\title{
Mesoscale convection system and occurrence of extreme low tropopause temperatures: observations over Asian summer monsoon region
}

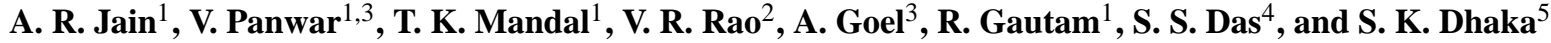 \\ ${ }^{1}$ Radio and Atmospheric Division, National Physical Laboratory, New Delhi, India \\ ${ }^{2}$ Satellite Meteorology Division, India Meteorology Department, Mausam Bhavan, New Delhi, India \\ ${ }^{3}$ Department of Physics and Astrophysics, University of Delhi, Delhi, India \\ ${ }^{4}$ Space Physics Laboratory, Vikram Sarabhai Space Center, Trivandrum, India \\ ${ }^{5}$ Department of Physics and Electronics, Rajdhani College, University of Delhi, New Delhi, India
}

Received: 14 December 2009 - Revised: 25 February 2010 - Accepted: 29 March 2010 - Published: 12 April 2010

\begin{abstract}
The present study examines the process of how tropospheric air enters the stratosphere, particularly in association with tropical mesoscale convective systems (TMCS) which are considered to be one of the causative mechanisms for the observation of extremely low tropopause temperature over the tropics. The association between the phenomena of convection and the observation of extreme low tropopause temperature events is, therefore, examined over the Asian monsoon region using data from multiple platforms. Satellite observations show that the area of low outgoing long wave radiation (OLR), which is a proxy for the enhanced convection, is embedded with high altitude clouds top temperatures $(\leq 193 \mathrm{~K})$. A detailed analysis of OLR and $100 \mathrm{hPa}$ temperature shows that both are modulated by westward propagating Rossby waves with a period of $\sim 15$ days, indicating a close linkage between them. The process by which the tropospheric air enters the stratosphere may, in turn, be determined by how the areas of convection and low tropopause temperature (LTT) i.e. $T \leq 191 \mathrm{~K}$ are spatially located. In this context, the relative spatial distribution of low OLR and LTT areas is examined. Though, the locations of low OLR and LTT are noticed in the same broad area, the two do not always overlap, except for partial overlap in some cases. When there are multiple low OLR areas, the LTT area generally appears in between the low OLR areas. Implications of these observations are also discussed. The present analysis also shows that the horizontal mean winds have a role in the spatial distribution of low OLR and LTT.
\end{abstract}

Correspondence to: A. R. Jain

(atma.jain@gmail.com)
Keywords. Meteorology and atmospheric dynamics (Tropical meteorology)

\section{Introduction}

To explain the observations of low water vapor mixing ratio over southern England, Brewer (1949) suggested that the observed stratospheric air must have passed through the tropical tropopause where the temperature is low enough to dry the air by freezing the water vapor. Extreme low tropopause temperatures are generally observed over western Pacific during November-March. Newell and Stewart (1981) have suggested that this region of low tropopause temperature expands in the north-west direction towards the Indian tropics during the spring and monsoon seasons (AprilSeptember). Jain et al. (2006) analyzed the observations of intense radiosonde/GPS-sonde campaigns, which were carried out over the Indian tropics, including the Bay of Bengal and adjacent area during monsoon and post-monsoon season, and noted that extreme low tropopause temperature $\left(T_{\mathrm{CPT}} \leq 191 \mathrm{~K}\right)$ do occur over these regions. Such extreme low tropopause temperatures are referred to, hereafter, as LTT.

Mesoscale tropical convective systems (TMCS) are considered to be one of the prime mechanisms for the generation of tropical LTT. Injection of cold air by convective overshoots followed by irreversible mixing was suggested by Danielsen (1982). Sherwood et al. (2003) have indicated that diabatic cooling by convective system just below the cold point tropopause (CPT) chills the air to a temperature lower than the CPT temperature, thus establishing a 
new CPT altitude. According to them the most likely explanation of diabatic cooling is the transport of cold air by penetrative clouds. Kim and Dessler (2004) have also argued that the mixing of cold air from overshooting convection is a potentially reasonable mechanism for the cooling of tropical tropopause layer (TTL), and this mechanism may also be important for determining the humidity in this layer. More recently, Pommereaue and Held (2007) have examined the impact of convection on the thermal structure of TTL using a series of radiosonde and weather S-band radar observations carried out during the HIBISCUS campaign in south Brazil in February 2004. They have shown that the injection of cold air explains partly the cooling of TTL associated with convection to which radiation, adiabatic lofting and Rossby and Kelvin Waves may also contribute. They have also noted that the afternoon overshoot and turbulent mixing is the only process that allows irreversible mixing.

It is apparent from the above discussion that the convection activity has a significant role in cooling the tropical tropopause region. However, what is currently not well understood is that how the tropospheric air penetrates into the lower stratosphere following a convection event. The process could be determined by the relative locations of the areas of convection and LTT. In case, these two phenomena are collocated, the injection of cold air by irreversible mixing of convection overshoots, as proposed by Danielsen (1982), may be the relevant mechanism. In that case, the air would be dehydrated while passing through the cold tropopause region provided this air stays for sufficient time in the cool tropopause region for the ice crystals to be formed and fallen out. Pommereaue and Held (2007) have shown that the injection of cold air by convection events in the upper troposphere and lower stratosphere (i.e. stratospheric fountain) is not an isolated event, but common over the land convection area. However, if the areas of convection and LTT are spatially separated, the entry of air from troposphere to lower stratosphere may not be a simple one-stage process. In that case the convective air may be rising into TTL up to a certain height (say level of neutral buoyancy) and from that point it may be rising slowly into the stratosphere (Holton and Gettelman, 2001; Gettelman et al., 2001; and Sherwood and Dessler, 2001). It is possible that some of the air rising into the stratosphere may return into the troposphere through the region of low temperature. In these cases the air in the upper troposphere region, close to tropopause, would be dry as inferred by Jain et al. (2006). It is, therefore, of interest to know how the areas of convection and LTT are spatially distributed. An important question is that if the convective activity has a role in cooling the tropopause then how the areas covered by these two phenomena (i.e. convective system and LTT) could be spatially separated. The cooling of the upper troposphere and lower stratosphere (UTLS) by convection takes a finite time approximately of $\sim 4-10 \mathrm{~h}$ or even longer (Kim and Dessler, 2004). Prevailing horizontal winds, in this time interval, could spatially redistribute the regions of convec- tive activity and of colder UTLS. This spatial redistribution would basically depend on the strength of background wind. Other mechanisms such as the wave activity associated with convection could also spread the cooling over substantial distances (Kuang and Bretherton, 2004).

In the present study the focus is on the features of the Asian summer monsoon region. There are, however, very limited observations existing over these regions during monsoon season. Cornford and Spavins (1973) measured the heights of cumulonimbus clouds that form during the premonsoon season (April-June) in north-east India, using air born radar, cameras and horizontal gyroscope. These clouds are found to extend up to $\sim 65000 \mathrm{ft}(\sim 20 \mathrm{~km})$. Cornford and Spavins (1973) have noted that the cumulonimbus clouds exceeding $60000 \mathrm{ft}(\sim 18 \mathrm{~km})$ occur on most of the measurement days. Bhat (2003) analyzed temperature data of active and weak phase of convection from observations taken on board ocean research vessel (ORV) Sagar Kanya (SK) during the Bay of Bengal Monsoon Experiment (BOBMEX) campaign (20 July-29 August 1999) over the Bay of Bengal and noted that temperature near the tropopause height during the active phase of convection is cooler by $\sim 2 \mathrm{~K}$ than that observed during the weak phase. This provided a direct evidence of the influence of convection activity on the temperature of the tropopause region. Kumar (2006) made use of observations by the Indian Mesosphere-StratosphereTroposphere (MST) Radar located at Gadanki $\left(13.45^{\circ} \mathrm{N}\right.$, $79.18^{\circ} \mathrm{E}$ ), a tropical station in India (Rao et al., 1995) and reported (a) enhanced mass fluxes across the tropopause and (b) enhanced gravity wave activity in the lower stratosphere during the passage of deep convection.

The main objective of the present study is twofold- first to examine the association between the phenomena of convection and the observation of LTT events and secondly to examine the spatial distribution of these two phenomena, which has a bearing on understanding of the process of troposphere -to-stratosphere transport of minor constituents, such as water vapor. Observations carried out on multiple platforms are, therefore, used for the present study. Daily observations are used to capture the fine scale features of OLR and LTT.

\section{Databases and methodology}

In the present study the (i) radiosonde/GPS-sonde observations of atmospheric temperature taken during BOBMEX period and (ii) data of cloud top temperature (CTT) and OLR obtained from the satellite INSAT-1D launched by the Indian Space Research Organization (www.isro.org) are used. Radiosonde measurements of atmospheric temperature, during BOBMEX, were carried out at seven stations (shown in Fig. 1). The radiosondes used in this campaign are IMD MK-III which has a height resolution of $\sim 300 \mathrm{~m}$ and the expected error in temperature measurements is $\sim 1.4 \mathrm{~K}$ at the level of $100 \mathrm{hPa}$ (Jain et al., 2006). 


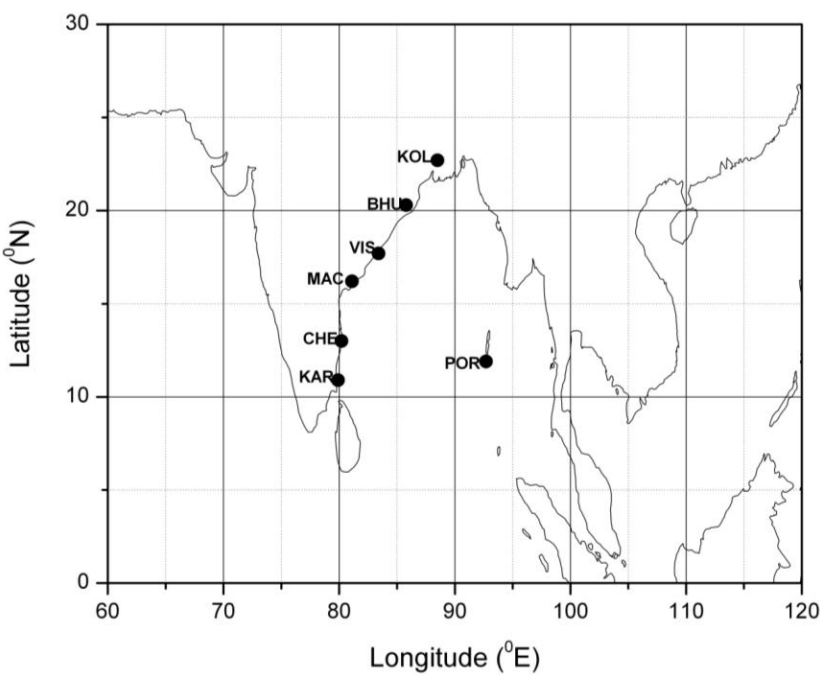

Fig. 1. Map showing the locations of the seven radiosonde stations operated during BOBMEX campaign period.

The GPS-sonde flights over the Bay of Bengal were carried out during BOBMEX onboard the ORV Sagar Kanya (Bhat et al., 2001; Bhat et al., 2002). The GPS-sonde, Vaisala model RS80-15G, used in this campaign was a standard instrument. The expected height resolution and error in temperature measurement for these instruments, near the level of tropopause, are better than $50 \mathrm{~m}$ and less than $1 \mathrm{~K}$, respectively. For this study the altitude of lowest temperature in the vertical profile (i.e. cold point tropopause (CPT)) has been taken as the level of tropopause. Radiosonde and GPS-sonde flights, for which CPT could be detected unambiguously, are used in the present study.

In addition to radiosonde observations, data from the geostationary satellite INSAT-1D, sub satellite point $\left(0^{\circ} \mathrm{N}\right.$, $74^{\circ} \mathrm{E}$ ) for BOBMEX campaign, are used to obtain spatial distribution of OLR and CTT. This satellite was operated from May 1990 to May 2002. It had a payload called the very high resolution radiometer (VHRR with two channels, viz. visible $(0.55-0.75 \mu \mathrm{m})$ and infrared channel $(10.5-12.5 \mu \mathrm{m})$. The resolution of visible image is $2.75 \mathrm{~km}$ and the same for infrared image is $11 \mathrm{~km}$. In addition to INSAT-1D data, high resolution imagery and cloud top temperature (CTT) are also obtained using International satellite cloud climatology project (ISCCP)-DX data for the period of BOBMEX observation. The ISCCP-DX data set is produced by the analysis of infrared (IR) and visible (day time only) radiances from weather satellite images with pixels about $5 \mathrm{~km}$ across (on the average), sampled at about $30 \mathrm{~km}$ and at about $3 \mathrm{~h}$ intervals (Rossow and Pearl, 2007). In these data sets, biases in (detectable) cloud amounts have been reduced to $\leq 0.05$, except the summertime polar-regions, where the bias may still be $\sim 0.10$. Biases in CTT are $\leq 2 \mathrm{~K}$ for lower level clouds and $\leq 4 \mathrm{~K}$ for optically thin, upper level clouds, except when they occur over lower-level clouds (Rossow and Schiffer, 1999).
Observations by the satellite Kalpana-1 for three days during July-August 2008, have been used to distinguish between the convective cloud system and the cirrus clouds. This satellite has a meteorological payload VHRR which provides images in visible $(0.55-0.75 \mu \mathrm{m})$, infrared $(10.5-12.5 \mu \mathrm{m})$ and water vapor $(5.7-7.1 \mu \mathrm{m})$ channels. The spatial resolution at the sub-satellite point is $2 \mathrm{~km}$ in visible channel and $8 \mathrm{~km}$ in infrared and water vapor channels. The infrared channel is, sometimes, referred as "clean channel" as it is comparatively less affected by the water vapor, whereas the water vapor channel is called "dirty channel", since this channel is sensitive to the presence of tropospheric water vapor. Observation of nearly the same temperature at the same pixels/areas by the clean and dirty channels indicates the presence of thick convective clouds (see http://www.nrlmry.navy.mil/). In addition to above satellite observations daily mean OLR data for the period 24 June-15 August 2002 are used from NOAA website.

Temperature and wind fields at $100 \mathrm{hPa}$ from European centre for medium-range weather forecasts (ECMWF) reanalysis data (ERA-40 model) have been examined. This analysis is carried out for monthly variations in the year 1999 and day-to-day variations during BOBMEX campaign period. The height level of $100 \mathrm{hPa}$ is selected as it denotes standard level near the tropopause. The spatial resolution of temperature reanalysis data set (ERA-40) used in this study is $\left(1.125^{\circ} \times 1.125^{\circ}\right)$.

Table 1 lists the stations and dates for which extreme low tropopause temperature $(\leq 191 \mathrm{~K})$ is observed at three or more stations including Sagar Kanya. It also gives the stations for which $T>191 \mathrm{~K}$. For the events listed in Table 1, simultaneous radiosonde/GPS-sonde data, INSAT-1D OLR data, and ECMWF reanalysis data sets are available. In addition to ECMWF data, National centers for environmental prediction (NCEP) reanalysis (Kalnay et al., 1996), data of daily mean temperature field at $100 \mathrm{hPa}$ level for the period 24 June-15 August 2002 are also used. The data sets, as mentioned above, provided a unique opportunity to understand better the influence of intense tropical convection on the temperature field at the levels close to the tropopause.

\section{Results and discussion}

\subsection{Seasonal movement of the intertropical convergence zone (ITCZ) and observations of monsoon associ- ated mesoscale convection events}

Seasonal movement of the ITCZ is well known. In the month of January, the ITCZ is normally located in the region of 12$15^{\circ} \mathrm{S}$. During summer monsoon, the ITCZ merges with the monsoon trough and in the month of July, the ITCZ is located in the region of $\sim 20-24^{\circ} \mathrm{N}$ latitude range (Holton et al., 2003). 
Table 1. List of date, time and stations for which CPT temperature $\left(T_{\mathrm{CPT}} \leq 191 \mathrm{~K}\right)$ is observed at three or more stations simultaneously. Stations for which $T_{\mathrm{CPT}}>191 \mathrm{~K}$ are also listed.

\begin{tabular}{|c|c|c|c|c|c|c|c|c|}
\hline \multirow{2}{*}{$\begin{array}{l}\text { S. } \\
\text { No. }\end{array}$} & \multirow[t]{2}{*}{ Date } & \multicolumn{3}{|c|}{ Radiosonde/GPS sonde observation stations } & \multicolumn{3}{|c|}{ S K observations } & \multirow{2}{*}{$\begin{array}{l}\text { OLR observation } \\
\text { Time } \\
\text { (GMT) }\end{array}$} \\
\hline & & $\begin{array}{l}\text { Temperature } \\
(\leq 191 \mathrm{~K})\end{array}$ & $\begin{array}{l}\text { Temperature } \\
(>191 \mathrm{~K})\end{array}$ & $\begin{array}{l}\text { Time of simultaneous } \\
\text { observations (GMT) }\end{array}$ & $\begin{array}{c}\text { Time of available } \\
\text { observations (GMT) }\end{array}$ & $\begin{array}{l}\text { Latitude } \\
\left({ }^{\circ} \mathrm{N}\right)\end{array}$ & $\begin{array}{l}\text { Longitude } \\
\qquad\left({ }^{\circ} \mathrm{E}\right)\end{array}$ & \\
\hline 1 & 28 Jul 1999 & CHE, POR, MAC, KAR & BHU, KOL, SK & 00:00 & $00: 30$ & 17.63 & 89.10 & 00:00 \\
\hline 2 & 29 Jul 1999 & CHE, POR, VIS & BHU. KOL & $12: 00$ & - & - & - & $12: 00$ \\
\hline 3 & 22 Aug 1999 & CHE, POR, SK & MAC, BHU, VIS, KOL & 00:00 & $00: 15$ & 17.05 & 89.03 & 01:00 \\
\hline 4 & 23 Aug 1999 & VIS, KOL, SK & CHE, POR & 00:00 & $00: 30$ & 17.26 & 88.72 & 00:00 \\
\hline 5 & 24 Aug 1999 & MAC, VIS, KOL, SK & CHE, POR & 00:00 & $00: 30$ & 18.04 & 88.01 & 00:00 \\
\hline 6 & 25 Aug 1999 & CHE, BHU, VIS, KOL & MAC & 18:00 & - & - & - & $18: 00$ \\
\hline 7 & 26 Aug 1999 & POR, VIS, KOL & CHE, MAC & $12: 00$ & - & - & - & $12: 00$ \\
\hline 8 & 26 Aug 1999 & BHU, VIS, KOL, SK & - & 18:00 & $17: 50$ & 13.79 & 88.21 & $15: 00$ \\
\hline 9 & 27 Aug 1999 & BHU, VIS, KOL & MAC, SK & $12: 00$ & $12: 00$ & 13.09 & 87.05 & $12: 00$ \\
\hline
\end{tabular}

KAR - Karaikal, POR - Port Blair, CHE - Chennai, MAC - Machilipatnam, VIS - Visakhapatnam, BHU - Bhubaneswar, KOL - Kolkata, SK - Sagar Kanya

Table 2. Cloud top temperature (CTT) and ECMWF reanalysis temperature over the region of cloud with cold CTT.

\begin{tabular}{|c|c|c|c|c|c|c|c|}
\hline \multirow{2}{*}{ S. No. } & \multirow{2}{*}{ Date } & \multirow{2}{*}{$\begin{array}{c}\text { Time } \\
\text { (GMT) }\end{array}$} & \multirow{2}{*}{$\begin{array}{l}\text { Latitude range } \\
\qquad\left({ }^{\circ} \mathrm{N}\right)\end{array}$} & \multirow{2}{*}{$\begin{array}{l}\text { Longitude range } \\
\qquad\left({ }^{\circ} \mathrm{E}\right)\end{array}$} & \multirow{2}{*}{$\begin{array}{c}\text { CTT range } \\
(\mathrm{K})\end{array}$} & \multicolumn{2}{|c|}{ ECMWF temperature $(\mathrm{K})$} \\
\hline & & & & & & Range & Mean \\
\hline 1 & 23 August 1999 & 00:00 & $9.0-12.4$ & $85.5-93.4$ & $173-193$ & 191.0-196.4 & 194.3 \\
\hline 2 & 23 August 1999 & 00:00 & $23.6-27.0$ & $81.0-90.0$ & $173-193$ & $192.1-194.7$ & 193.4 \\
\hline 3 & 24 August 1999 & 00:00 & $11.25-15.08$ & $79.9-85.5$ & $173-193$ & 192.6-197.2 & 194.6 \\
\hline 4 & 24 August 1999 & 00:00 & $2.3-6.8$ & $108.0-112.5$ & $173-193$ & 189.9-191.4 & 190.7 \\
\hline 5 & 25 August 1999 & 00:00 & $21.4-27.0$ & $105.8-110.3$ & $173-193$ & $193.0-196.9$ & 195.3 \\
\hline
\end{tabular}

After the meteorological centers have started receiving satellite pictures of cloud systems on routine, the ITCZ is defined in terms of maximum cloudiness. This is due to the fact that the ITCZ is accompanied by an organized band of clouds. Some of these are convective clouds. This makes it feasible to use OLR for the detection of the ITCZ. Okoola (1998) used OLR to study spatial evaluation of the active convection pattern across the equatorial eastern Africa region during spring season in the Northern Hemisphere. In present study seasonal movement of the ITCZ, during the year 1999, is examined using monthly average OLR data from INSAT1D. Figure 2 shows location of the ITCZ (solid line) for the months of January 1999 and July 1999. In Fig. 2, spatial distribution of monthly mean temperature at $100 \mathrm{hPa}$ level from ECMWF reanalysis is also plotted. A careful examination of Fig. 2 shows that in the month of January both the ITCZ and minima in $100 \mathrm{hPa}$ temperature lie south of the equator, whereas in July both the ITCZ and minima in $100 \mathrm{hPa}$ temperature lie north of the equator, indicating similarity in the seasonal movement and a close association between the two phenomena. The ITCZ is generally associated with intense convection activity. Therefore, with movement of the ITCZ to the northward and its merging with the monsoon trough indicates that monsoon-associated convection must occur over the Indian tropical region and this is, indeed, the case. Fig- ure 3 shows INSAT-1D imageries for three days along with corresponding OLR distribution maps. Following important points may be noted from Fig. 3 .

1. Cloud top temperature (CTT) as low as $193-173 \mathrm{~K}$ is observed over these areas. This indicates that cloud top is at a height $\geq 17 \mathrm{~km}$.

2. Clouds with such cold top temperature are noted to be located in the low OLR areas as seen from OLR contour maps.

The low CTT, as observed in Fig. 3, are compared with $100 \mathrm{hPa}$ ECMWF reanalysis temperature field over these areas. Table 2 gives a comparison of the observed CTT and the reanalysis temperature at $100 \mathrm{hPa}$ level, which is taken to be representative of ambient temperature. It can be noted from Table 2 that, in general, CTT temperature is lower by $\sim 10 \mathrm{~K}$ than the ambient temperature. This indicates the presence of clouds with CTT cooler than the surroundings.

To examine (i) whether deep penetrating convective systems with cold tops really occur over the Indian region and (ii) to distinguish such convective clouds system from cirrus, 3 days observational data obtained from Kalpana-1 satellite during July-August 2008 are used (Fig. 4). Some locations (i.e. same pixels/area) where the temperature from clean and dirty channels is close enough (i.e. with in $10 \mathrm{~K}$ ) are marked 

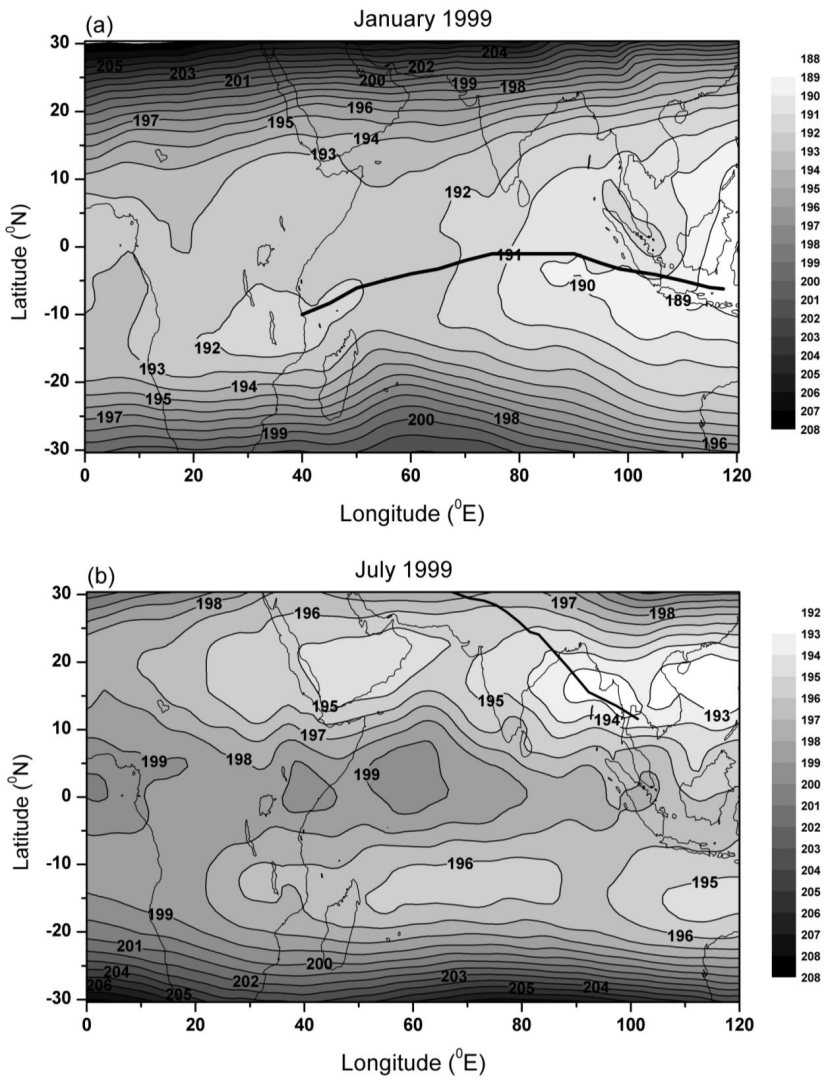

Fig. 2. Plot of contour maps of monthly mean temperature field at $100 \mathrm{hPa}$ level from ECMWF reanalysis. Solid line shows location of ITCZ as determined using monthly mean OLR distribution from satellite INSAT-1D. (a) January 1999, (b) July 1999.

with arrows in Fig. 4, indicating the presence of thick convective clouds at these locations (http://www.nrlmry.navy.mil/). Right hand panels in Fig. 4 show high resolution OLR observations $\left(0.25^{\circ} \times 0.25^{\circ}\right)$ from Kalpana-1 satellite corresponding to imagery in the left hand panels. It is evident from Fig. 4 that locations of close temperatures from infrared (clean) and water vapor (dirty) channels lie within the area of low OLR, i.e. OLR $\leq 160 \mathrm{~W} \mathrm{~m}^{-2}$ which is consistent with the presence of convection representing CTT $\leq 235 \mathrm{~K}$ corresponding to the altitude of $\leq 200 \mathrm{hPa}$ (i.e. $\geq 12 \mathrm{~km}$ ). These results are consistent with those of Cornford and Spavins (1973) who have observed clouds extending up to $65000 \mathrm{ft}$ $(\sim 20 \mathrm{~km})$ and also noted that cumulonimbus clouds exceeding $60000 \mathrm{ft}(\sim 18 \mathrm{~km})$ occurred on most of the measurements days.

Monsoon-associated mesoscale convection is considered as one of the source mechanisms for cooling the tropopause. It would, therefore, be interesting to examine the occurrence of mesoscale convection and its association with occurrence of LTT.
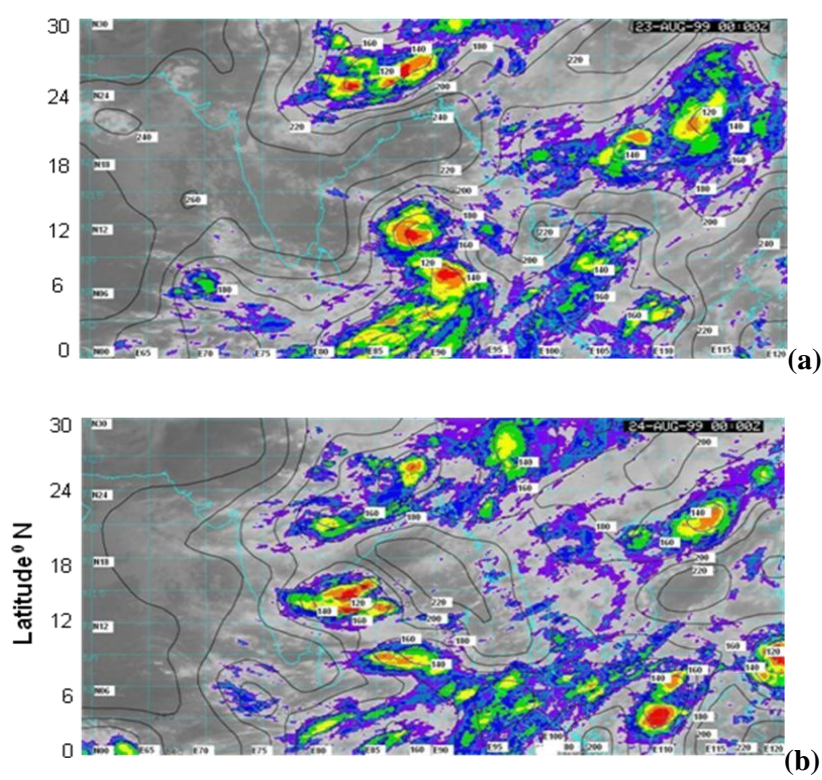

(b)
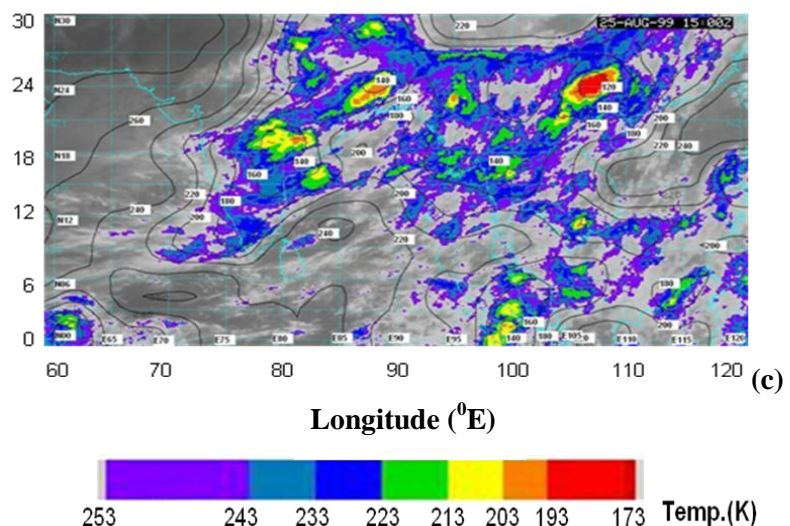

Fig. 3. INSAT-1D imagery along with cloud top temperature (CTT) are shown for three events. Contour maps of OLR $\left(\mathrm{W} \mathrm{m}^{-2}\right)$ are drawn in black lines. Separation between OLR lines is $20 \mathrm{~W} \mathrm{~m}^{-2}$. Three panels of this figure correspond to (a) 23 August 1999, 00:00 GMT, (b) 24 August 1999, 00:00 GMT and (c) 25 August 1999, 15:00 GMT.

\subsection{Occurrence of low temperature in tropopause re- gion in association with convection activity}

In the present study, to examine the spatial distribution of the areas of enhanced convective systems, OLR has been used as a proxy for cloud/convective system. However, caution should be taken when interpreting OLR as a convection/rainfall, since thick, high clouds can produce identical OLR as connective cloud, while substantially different production of rainfall occur between the two cloud types (Lyons, 1991). In the present study following four approaches have been adopted to examine the spatial distribution of enhanced convection activity (i.e. low OLR) and of low temperature in tropopause region. 


\section{0 \\ 30 \\ 20}

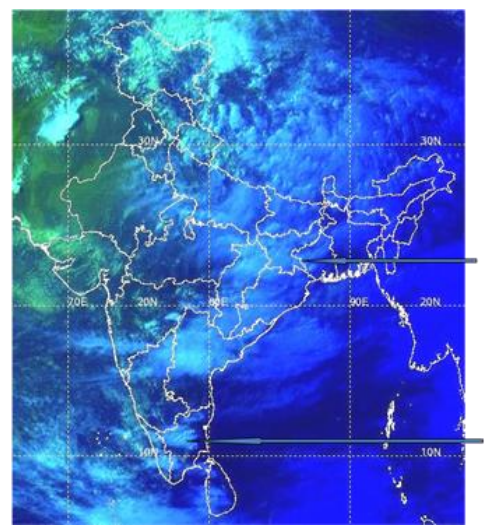

KALPANA-1 18/07/2008

12 UTC

Clean $=207 \mathrm{~K}$
Dirty $=202 \mathrm{~K}$

$22.45 \mathrm{~N} / 85.43 \mathrm{E}$

18/07/2008

12 UTC

Clean $=211 \mathrm{~K}$

Dirty $=202 \mathrm{~K}$
$11.05 \mathrm{~N} / 77.90 \mathrm{E}$

40

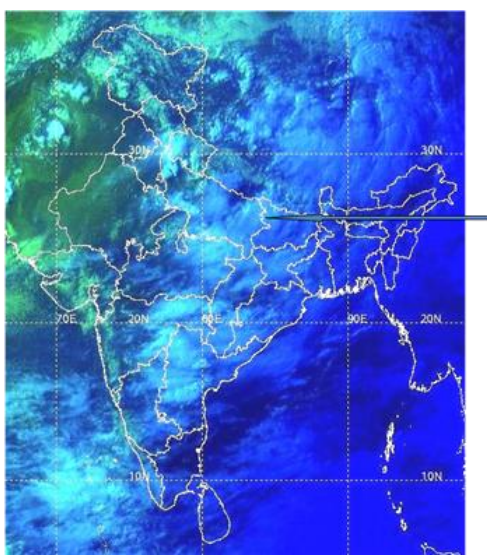

KALPANA-1

19/07/2008

12 UTC

Clean $=201 \mathrm{~K}$

Dirty $=194 \mathrm{~K}$
$26.22 \mathrm{~N} / 83.72 \mathrm{E}$

20

10

40

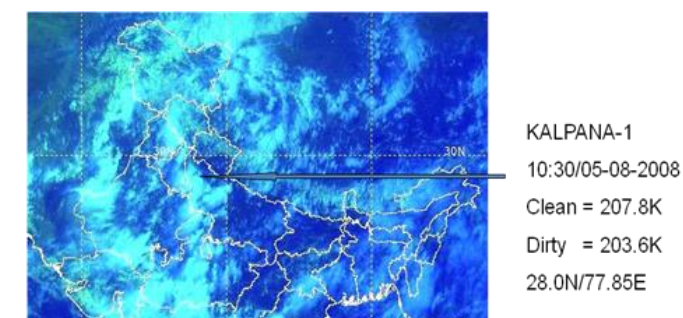

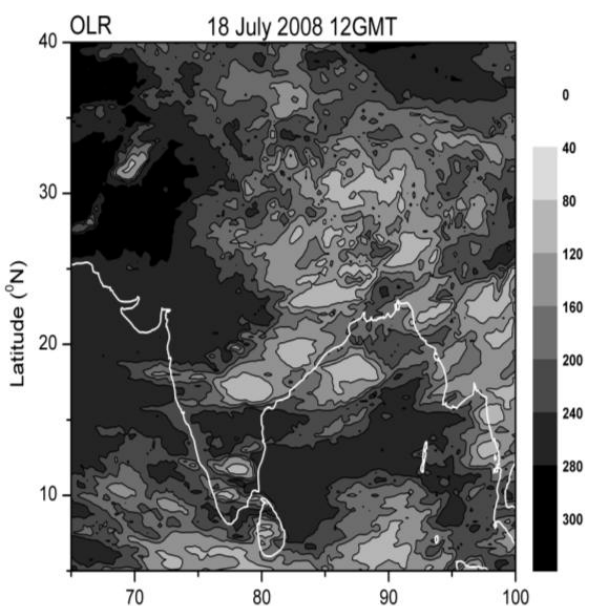

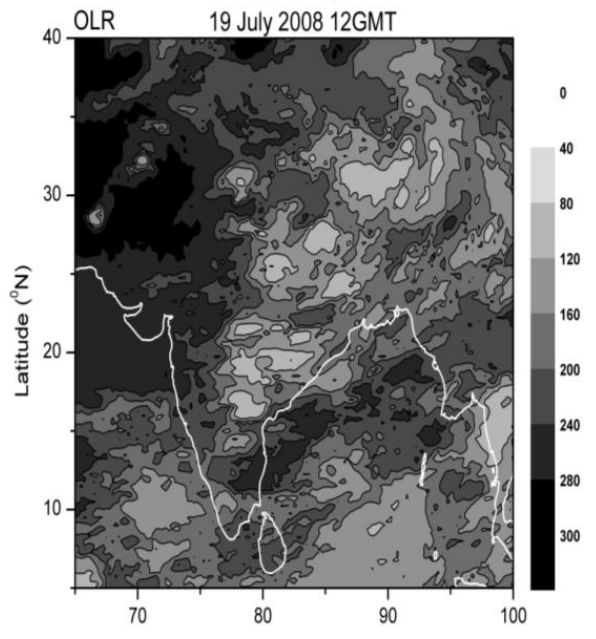

Longitude $\left({ }^{\circ} \mathrm{E}\right)$

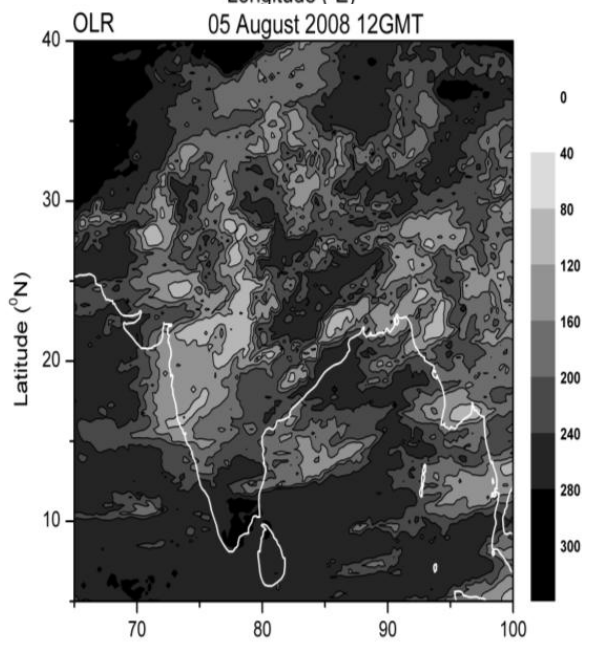

Longitude $\left({ }^{0} \mathrm{E}\right)$

Fig. 4. Panels on left side show false color imagery (using Visible and Infrared channels) for three recent events from Kalpana-1 satellite. The temperatures noted on the map are identified using infrared (clean) and water Vapor (dirty) channels using separate tool. Some of the locations where the temperature from two channels is within $\sim 10 \mathrm{~K}$ are marked with arrow. Geographic coordinates of these points are also mentioned. Right side panels show OLR contour maps, from Kalpana-1 satellite, corresponding to imagery shown on left side. OLR with values $\leq 160 \mathrm{~W} \mathrm{~m}^{-2}$ are shown by light grey color. 

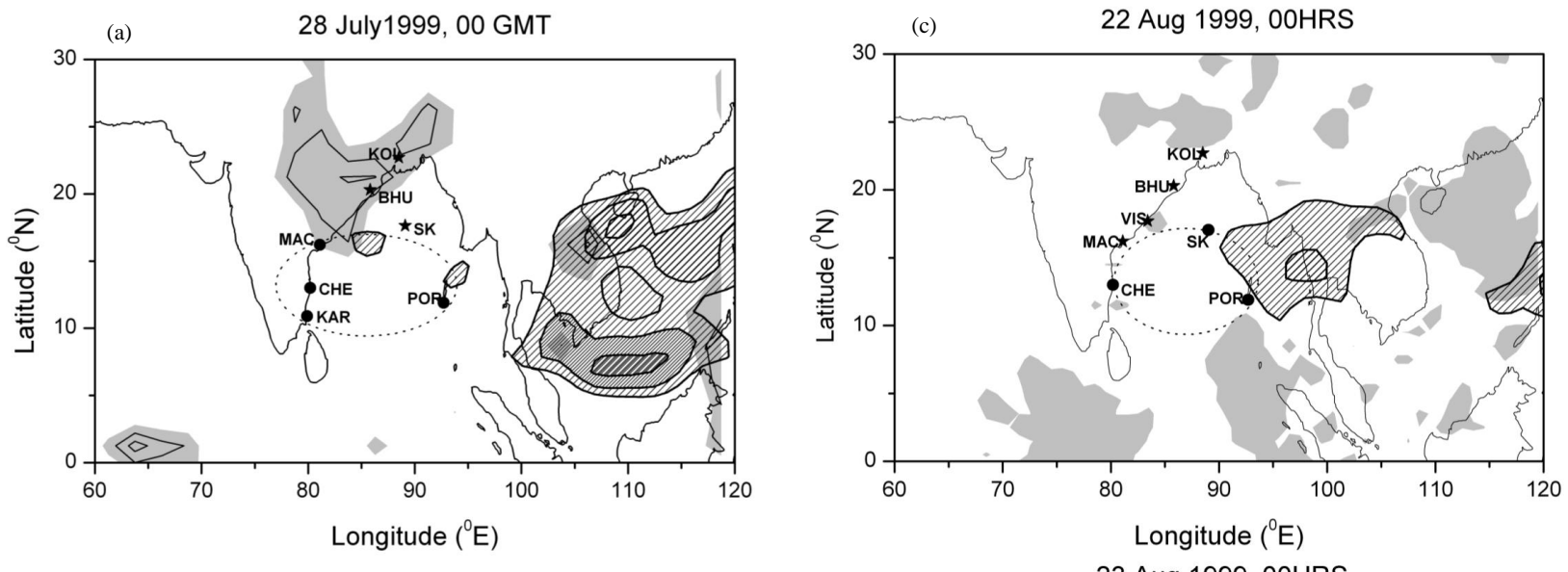

(b)

29 July 1999, 12HRS
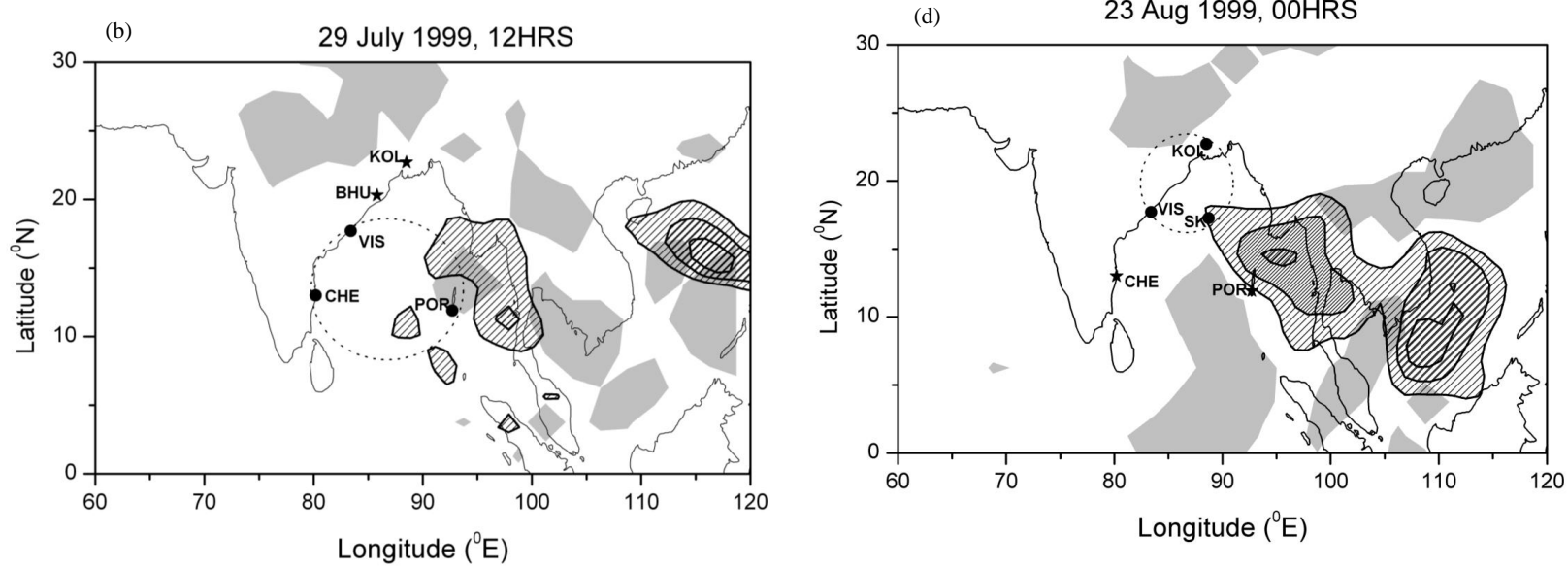

Fig. 5. Figure shows plots of locations of Radosonde/GPS Sonde stations with $T_{\mathrm{CPT}} \leq 191 \mathrm{~K}$ which are marked with filled circles. These points are joined with a smooth curve drawn with dashed lines. Radiososonde/GPS Sonde stations with $T_{\mathrm{CPT}}>191 \mathrm{~K}$ are shown by Stars for distinction. Contour maps of low OLR (i.e. $\leq 160 \mathrm{~W} \mathrm{~m}^{-2}$, and that of low $T_{100}$ (i.e. $T_{100} \leq 191 \mathrm{~K}$ ) from ECMWF reanalysis temperature data are shown. Areas of low OLR are shaded with grey and areas of low $T_{100}$ temperature are hatched. (a) 28 July 1999, 00:00 GMT, (b) 29 July 1999, 12:00 GMT, (c) 22 August 1999, 00:00 GMT, (d) 23 August 1999, 00:00 GMT, (e) 24 August 1999, 00:00 GMT, (f) 25 August 1999, 18:00 GMT, (g) 26 August 1999, 12:00 GMT, (h) 26 August 1999, 18:00 GMT and (i) 27 August 1999, 12:00 GMT.

\subsubsection{Radiosonde/GPS-sonde observations and OLR from INSAT-1D satellite}

Radiosonde/GPS-sonde observations taken during BOBMEX campaign and simultaneous OLR observations by INSAT-1D satellite are examined. All the cases with observations of low CPT temperature $\left(T_{\mathrm{CPT}} \leq 191 \mathrm{~K}\right)$ at 3 or more stations including Sagar Kanya (listed in Table 1), are studied in detail. Figure 5 shows all the 9 cases listed in Table 1. In Fig. 5 stations with $T_{\mathrm{CPT}} \leq 191 \mathrm{~K}$ are shown by filled circle and stations with $T_{\mathrm{CPT}}>191 \mathrm{~K}$ are marked with stars. Stations having low $T_{\mathrm{CPT}}$ are joined by a smooth curve (dashed line) to indicate the area of low $T_{\mathrm{CPT}}$ temperature as defined by radiosonde/GPS-sonde stations. In addition, Fig. 5 also shows areas of observation of low OLR, i.e. OLR $\leq 160 \mathrm{~W} \mathrm{~m}^{-2}$ (shaded grey). Spatial distribution of low $T_{\mathrm{CPT}}$ and that of low OLR can be observed from Fig. 5. Two important points may be noted from Fig. 5: (i) On day-to-day basis, areas of low $T_{\mathrm{CPT}}$ and that of low OLR are observed in the same broad area, but are not always overlapping. In such cases the values of OLR at the locations of low $T_{\mathrm{CPT}}$ are greater than $160 \mathrm{~W} \mathrm{~m}^{-2}$. However, on some occasions, some of the areas of low $T_{\mathrm{CPT}}$ and low OLR are observed to overlap or partially overlap as seen clearly from panels (e), (f), (g), (h) and (i) of Fig. 5. (ii) On a number of occasions, multiple areas of low OLR are observed. In such cases, areas of low $T_{\mathrm{CPT}}$ appear in between the centers of low OLR as seen clearly from panels (b), (c), (d) (e), (f), (g), (h) and (i) of Fig. 5. It, however, it may be mentioned here that the radiosonde /GPS-sonde stations provided only a limited spatial coverage. To overcome this difficulty, temperature field at $100 \mathrm{hPa}$ level $\left(T_{100}\right)$ and from ECMWF and NCEP reanalysis is examined. 

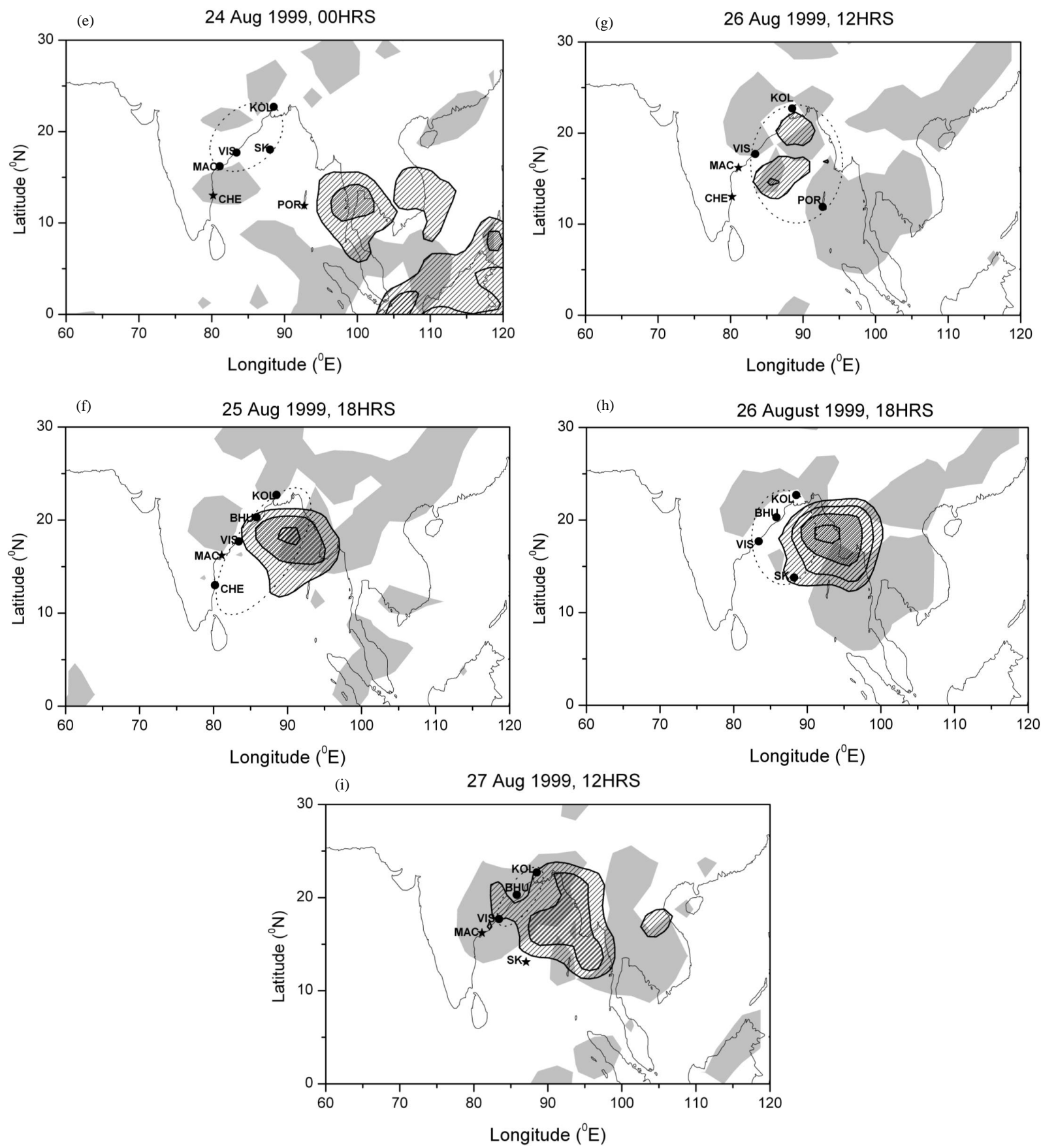

Fig. 5. Continued.

\subsubsection{ECMWF reanalysis temperature at $100 \mathrm{hPa}$ level and OLR from INSAT-1D satellite}

In this approach ECMWF reanalysis temperature data (M100 model) at $100 \mathrm{hPa}$ level $\left(T_{100}\right)$ with a spatial resolution of $1.125^{\circ} \times 1.125^{\circ}$ and simultaneous OLR observations from INSAT-1D are examined. Figure 5 shows all the 9 cases listed in Table 1. In Fig. 5 areas covered by low $T_{100}$ are hatched and areas of low OLR, i.e. OLR $\leq 160 \mathrm{~W} \mathrm{~m}^{-2}$ are shaded grey (as mentioned in Sect. 3.2.1). Figure 5 also shows that areas of low $T_{100}$ and low OLR are not always collocated, though they are located in same broad area. On some days, some of the areas of low OLR and low $T_{100}$ are noted to overlap/partially overlap as seen more clearly from panels (f), (g), (h) and (i) of Fig. 5. On some days, multiple centers of low OLR are also observed. In such cases, areas 
of low $T_{100}$ tend to be located in between the centers of low OLR which is more evident from panels $(\mathrm{d}-\mathrm{i})$ of Fig. 5.

\subsubsection{Daily mean $T_{100}$ from NCEP reanalysis data and daily mean OLR data}

Observations in Sects. 3.2.1 and 3.2.2 are based on simultaneous measurements of OLR and $T_{100} / T_{\mathrm{CPT}}$ for 9 days. To examine spatial distribution of OLR and $T_{100}$ for a longer period, 54 days data (24 June-15 August 2002) are used. Daily mean OLR is obtained from NOAA website and daily mean $T_{100}$ field is taken from NCEP reanalysis. Extreme low temperatures (i.e. $T_{100} \leq 191 \mathrm{~K}$ ) are observed for 29 days. Low $T_{100}$ and low OLR are observed to occur over the same broad area, though all OLR and low $T_{100}$ areas do not overlap (see Auxiliary Material File 1 in http://www.ann-geophys.net/28/ 927/2010/angeo-28-927-2010-supplement.zip). It may be mentioned here that in such cases, OLR is greater than $160 \mathrm{~W} \mathrm{~m}^{-2}$ at the location of low $T_{100}$. However, in some cases, some of the low OLR and low $T_{100}$ areas are found to be overlapped or partially overlapped. Multiple patches of OLR are observed on number of days. Out of 29 days of low $T_{100}$ observations, on 24 days, area of low $T_{100}$ is observed in between the areas of multiple low OLR. This indicates that in these cases, low $T_{100}$ is produced either by independent multiple centers of convection activity or by one single convection event fragmented by wind pattern. These observations suggest that the mechanism suggested by Danielsen (1982) is operating in the cases where the areas of low OLR and low $T_{100}$ are overlapping or partially overlapping. In some cases, when these two areas are not overlapping, such as the case when low $T_{100}$ appears in between the multiple centers of low OLR, the mechanism suggested by Sherwood (2000) is more likely to be operating. It is likely that on some days, both the mechanisms are operating, but at somewhat different geographical locations.

\subsubsection{Analysis of time series of daily mean $T_{100}$ and daily mean OLR}

The results shown here bring out a close association between enhanced convection activity and occurrence of low $T_{100} / T_{\mathrm{CPT}}$. This association is further examined using time series of daily mean OLR data from NOAA website and daily mean $T_{100}$ data from NCEP reanalysis for the period of 24 June-15 August 2002. This particular period was selected as the necessary OLR and NCEP reanalysis data were readily available. Two specific regions, viz. Indian land mass (ILM: $10-20^{\circ} \mathrm{N}, 72.5-82.5^{\circ} \mathrm{E}$ ) and Bay of Bengal (BOB: $\left.10-20^{\circ} \mathrm{N}, 85-90^{\circ} \mathrm{E}\right)$ are selected and daily mean OLR and $T_{100}$ are averaged over these areas. Panels (a) and (b) of Fig. 6 show the time series of anomaly in OLR and $T_{100}$ over the BOB and ILM regions, respectively. Panels (c) and (d) of Fig. 6 show the corresponding spectrum obtained using a fast Fourier transform (FFT) algorithm which applies de-trending
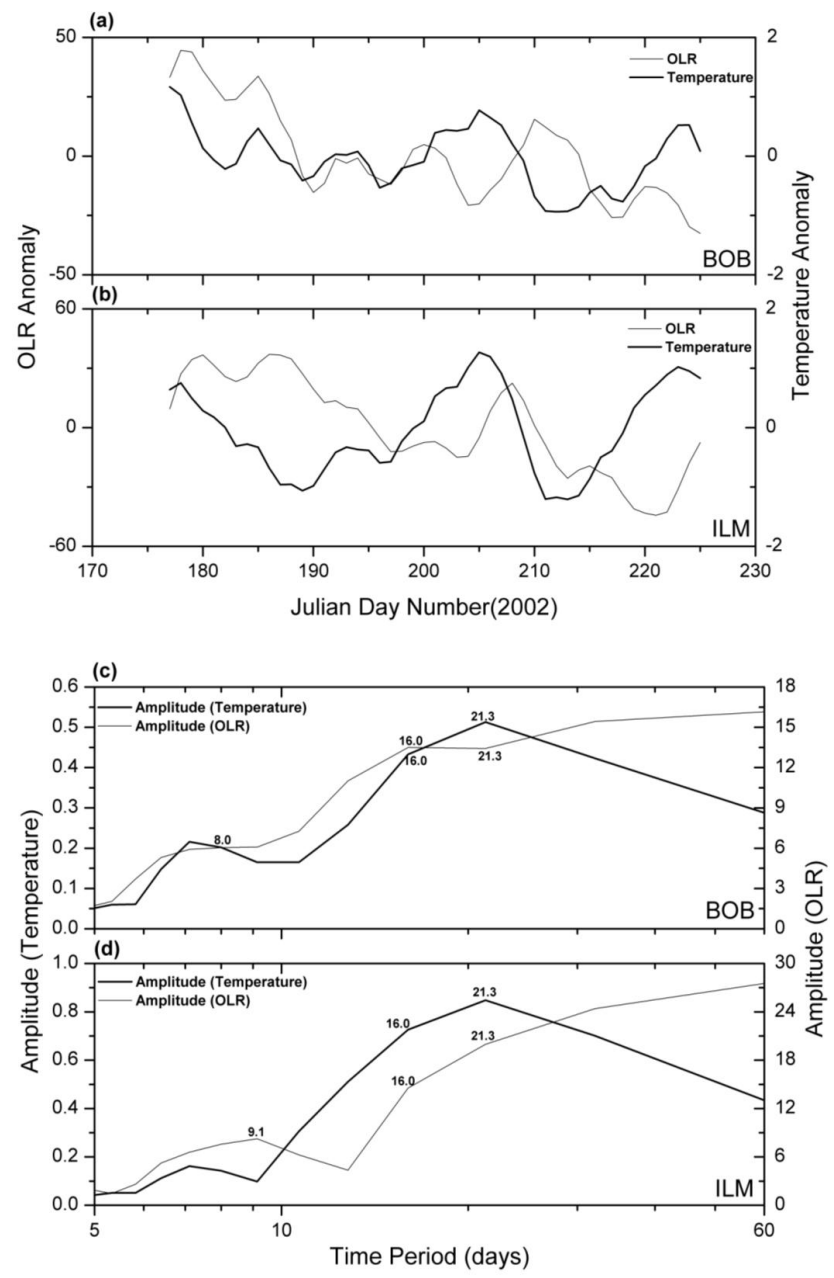

Fig. 6. Time series of OLR and Temperature at $100 \mathrm{hPa}$ level $\left(T_{100}\right)$ anomaly for the ARMEX campaign period over (a) Bay of Bengal (BOB) and (b) Indian Land Mass (ILM) regions. Spectrum corresponding to these time series are shown in panels (c) and (d), respectively.

and necessary Hanning window (Blackman and Tukey, 1959) before taking FFT. Running mean over 5 days was taken for each series before applying FFT to filter out oscillations with period of $<5$ days. Spectrum of temperature and OLR time series show a broad peak with a period of 16-21 days. The OLR spectrum over BOB region shows an additional peak at 7-9 day period. Jain et al. (2010), using Arabian Sea Monsoon Experiment (ARMEX) campaign data, have shown that westward propagating Rossby waves of period of $\sim 15$ days and eastward propagating intraseasonal oscillation modulate temperature at $100 \mathrm{hPa}$ level during summer monsoon season. Figure $6 \mathrm{a}, \mathrm{b}$ shows that waves of period of $\sim 15$ days modulate OLR as well as $T_{100}$. Therefore, this particular oscillation is selected by passing the OLR and $T_{100}$ anomaly time series through a band pass filter of 13-18 days period. Spectra of filtered time series are obtained using FFT 

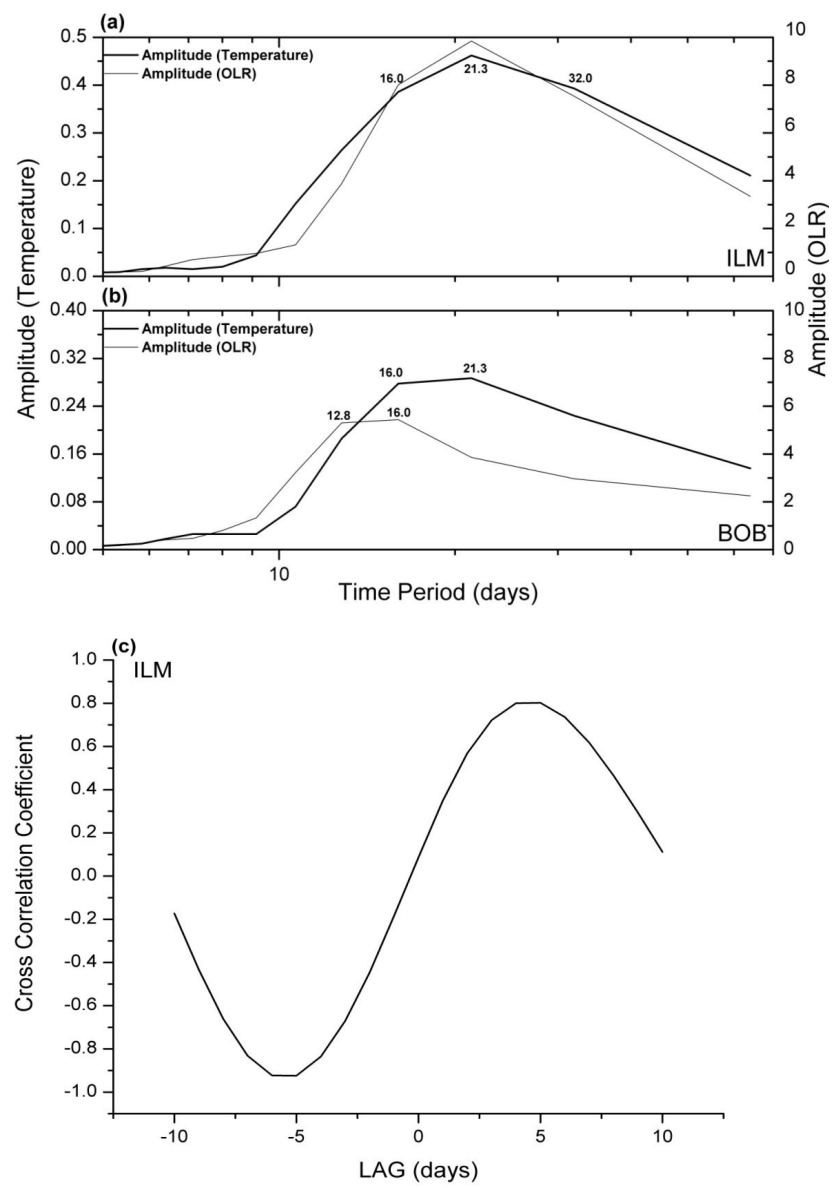

Fig. 7. Spectrum of OLR and $T_{100}$ anomaly time series over ILM BOB regions, after passing through a band pass filter of 1318 days period, are shown in panel (a) and (b), respectively and panel (c) shows cross correlation function between $T_{100}$ and OLR time series over ILM region.

technique and the same are shown for ILM and BOB regions in Fig. $7 \mathrm{a}$, b. It is apparent from Fig. 7 that OLR and $T_{100}$ spectrum over ILM region is similar. The spectra of OLR and $T_{100}$ differ slightly over BOB, because short-period waves (13-16 days period) are dominant in modulating OLR over this region. Since the two sets of spectra are similar over ILM region, a cross-correlation analysis is carried out. Figure 7c shows the cross-correlation function between $T_{100}$ and OLR time series over this region with OLR leading in phase by $\sim 5$ days. Observations of low OLR and its variability are supposed to be the active source region for the generation of atmospheric waves. In this case, Rossby waves are identified to be present in the ILM region (Fig. 7). Westward movement of OLR with leading in phase in comparison to temperature suggests that quasi-periodic behavior of the source (convection i.e. OLR) has generated this wave mode in the upper troposphere and the delay of $\sim 5$ days represents the time taken for the energy transfer to the medium which oscillates in resonance with the same characteristics.

\subsection{Role of horizontal winds and convection generated gravity waves in spatial distribution of areas of low $T_{100}$ and of low OLR}

A close association between OLR and $T_{100} / T_{\mathrm{CPT}}$ is evident from the results presented in Sect. 3.2. This suggests that spatial distribution of these two parameters must be related to the processes involved in cooling the tropopause region by convection. This would throw light on the mechanism of intrusion of tropospheric air into stratosphere. There are the following two types of processes through which convection could cool the tropopause region and then redistribute spatially the regions of low temperatures at the tropopause level.

1. Convection is cooling the tropopause region directly as mentioned earlier (Danielsen, 1982; Vomel et al., 1995; Titelbam et al., 2000; Gettleman et al., 2002; Sherwood et al., 2003; Sherwood and Dessler, 2003; Kim and Desseler, 2004; Jiang et al., 2004, and Pommereau and Held, 2007). Horizontal winds and associated advection subsequently determine the spatial distribution of areas of low OLR (convective cloud systems) and of tropopause temperature.

2. The convection-generated gravity waves penetrating to UTLS are modulating the temperature of the region and, in turn, spreading the cooling to the other areas (Tsuda et al., 1994; Potter and Holton, 1995; Kuang and Bretherton, 2004; and Dhaka et al., 2006).

An attempt is now made to examine the role of each of the above processes in determining the relative spatial distribution of convection activity and low tropopause temperature.

\subsubsection{Role of horizontal winds}

Horizontal wind and associated advection could have a role in determining the spatial distribution of the areas of low OLR and of low $T_{100}$. It takes some time for convection to cool the tropopause region, which could be $\sim 4-10 \mathrm{~h}$ or even longer (Kim and Desseler, 2004). In this time interval, winds could shift the location of convective systems and thus the areas of both low OLR and $T_{100}$ may appear spatially separated. The period 24 August 1999, 00:00 GMT-28 August $1999,18: 00$ GMT is selected to examine the role of horizontal winds, based on the synoptic situation (Morwal and Kumar, 2002) prevailing over the Indian tropical region during this period which is briefly described below:

On 24 August 1999, a low pressure area was formed over west central Bay off the north Andhra coast which persisted till 25 August. An associated cyclonic circulation extended up to mid-tropospheric levels. Another low pressure system was formed on 26 August over north-west Bay off the Orissa coast and the associated cyclonic circulation extended up to mid-tropospheric levels tilting south-westwards with height. On 27 August, the low pressure area over north-west Bay off 


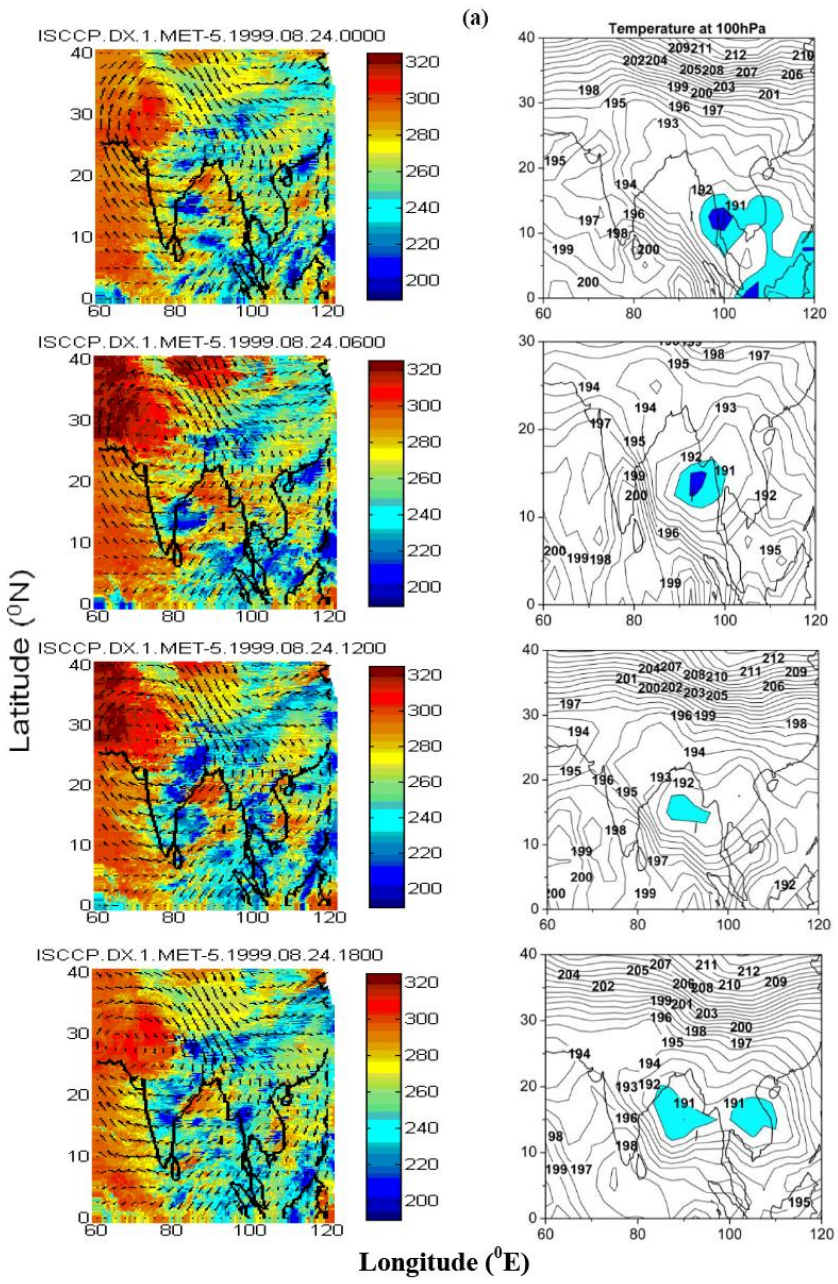

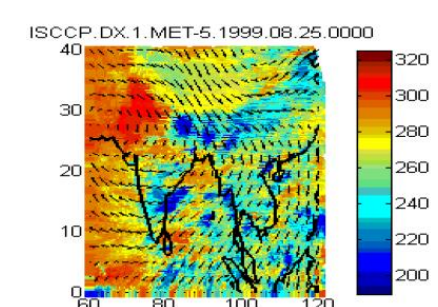
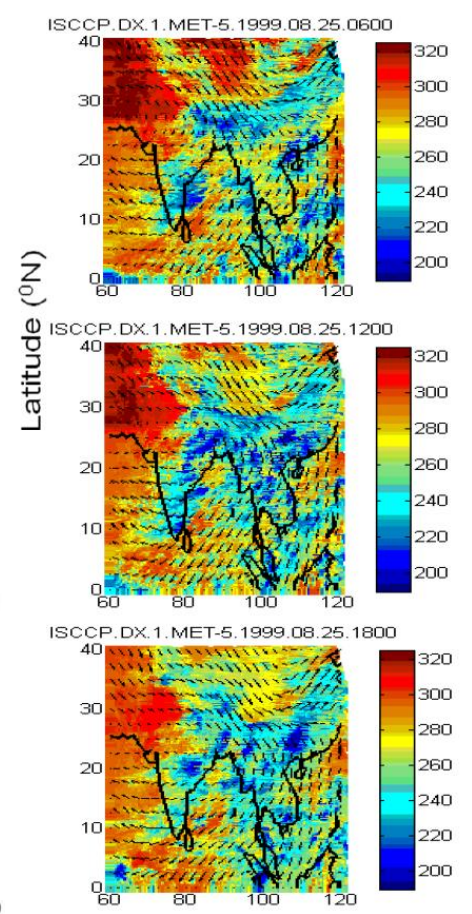

Longitude $\left({ }^{0} \mathbf{E}\right)$ (b)
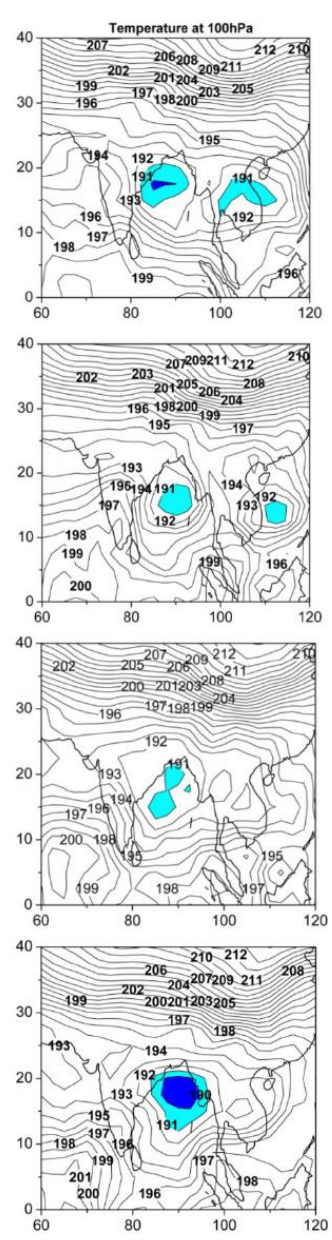

Fig. 8. Left hand side panels show satellite imageries drawn using 6 hourly ICSSP-DX data. Horizontal wind field at $100 \mathrm{hPa}$ level, corresponding to each of the satellite imagery, from ECMWF reanalysis is superposed. Right hand side panels show contour maps of temperature field at $100 \mathrm{hPa}$ level. Contours of low $T_{100}$ temperature are shaded blue. Resolution of ECMWF reanalysis data presented in this particular figure is $2.5^{\circ} \times 2.5^{\circ}$. (a) 24 August 1999, 00:00 GMT to 24 August 1999, 18:00 GMT. (b) 25 August 1999, 00:00 GMT to 25 August 1999, 18:00 GMT.

the Orissa coast, was found to lie over north-west Bay, off West Bengal - north Orissa coast. This low pressure area was located over north Bay off West Bengal - Bangladesh coasts on 28 August and the associated cyclonic circulation extended up to $3.6 \mathrm{~km}$ above sea level (a.s.l.). These synoptic conditions indicate active monsoon conditions over northcentral Bay of Bengal and the adjoining coastal areas. Active monsoon conditions during the above period are also evident from ECMWF reanalysis of horizontal wind for the period 20 August-28 August 1999 . Easterly jet winds are noted to be dominant between 10 and $20^{\circ} \mathrm{N}$ till 22 August 1999 (not shown). These winds remain north-easterly for the period 23 August 1999 onwards between $10-20^{\circ} \mathrm{N}$ and $75-120^{\circ} \mathrm{E}$. High spatial resolutions, 6 hourly imageries from ISCCP-DX data and corresponding wind and temperature from ECMWF reanalysis for the same period are utilized to examine the role of horizontal winds. Figure 8 shows the ISCCP-DX imageries of 24 and 25 August 1999. Horizontal wind vectors at $100 \mathrm{hPa}$ level are superposed on ISCCP-DX imagery and are shown in the left side panels of Fig. 8. The right hand side panels show corresponding contour maps of temperature field at $100 \mathrm{hPa}$ level from ECMWF reanalysis. Areas corresponding to low $T_{100}$ (i.e. $T_{100} \leq 191 \mathrm{~K}$ ) are shaded blue. Following important points may be noted from Fig. 8.

1. North-easterly winds are prevailing over the Bay of Bengal and adjoining areas such as North-East India, Bangladesh, Myanmar, Indo-China and Thailand. The cloud systems over the Bay of Bengal and the adjoining areas, as a whole appear to move in response to the prevailing winds. 

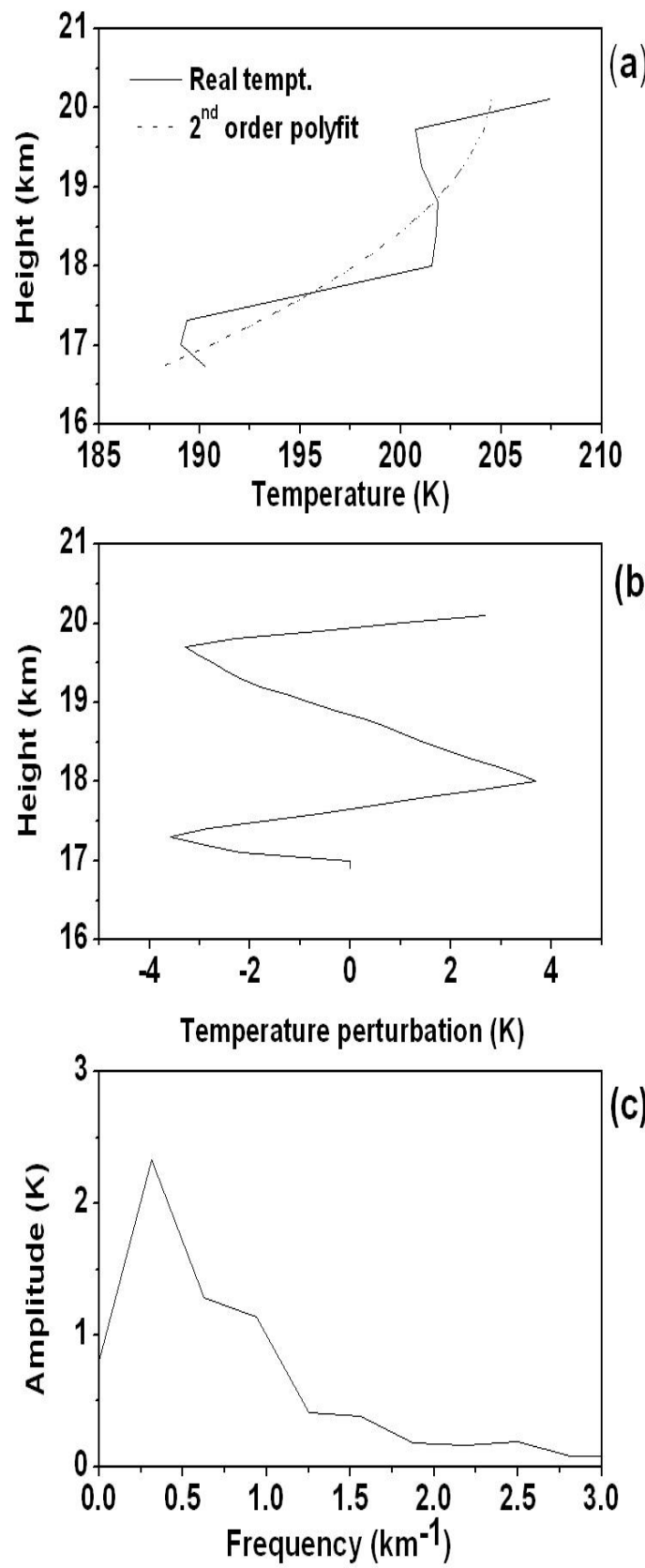

Fig. 9. Figure shows signature of temperature modulation by convection generated wave activity. (a) Vertical temperature profile taken on 24 August 1999, 00:00 GMT using GPS Sonde launched from ORV Sagar Kanya, (b) temperature perturbation from mean trend and (c) spectrum of the temperature perturbation from mean trend in the height profile of temperature.

2. The cloud systems seem to be weaken/dissipated by the time these systems could reach the longitude belt of $70-75^{\circ} \mathrm{E}$ and then a new system forms in the easterncentral Bay of Bengal close to $100-120^{\circ} \mathrm{E}$. The areas of low $T_{100}$ also seem to follow the movement of the cloud systems and these areas are also observed to confine to
Table 3. Vertical wavelength of the wave activity in UTLS.

\begin{tabular}{lcc}
\hline Date & Time $(\mathrm{GMT})$ & Vertical wavelength $(\mathrm{km})$ \\
\hline 28 July 1999 & $12: 15$ & 2 \\
12 August 1999 & $00: 40$ & 2.1 \\
22 August 1999 & $00: 15$ & 9.6 \\
23 August 1999 & $00: 30$ & 4.5 \\
24 August 1999 & $00: 30$ & 3.2 \\
25 August 1999 & $06: 00$ & 1.25 \\
26 August 1999 & $00: 10$ & 1.4 \\
26 August 1999 & $17: 50$ & 1.4 \\
27 August 1999 & $00: 30$ & 1.2 \\
\hline
\end{tabular}

the east of $70-75^{\circ} \mathrm{E}$ longitude range as is the case with cloud systems.

3. The areas of low $T_{100}$ generally appear between the cloud systems, though some of the low $T_{100}$ areas may overlap or partially overlap the location of some of the cloud systems.

4. Speed of the westward movement of the cloud and low $T_{100}$ systems, is $\sim 10 \mathrm{~ms}^{-1}$, which is consistent with the expected phase velocity of Rossby waves.

These observations (see Auxiliary Material File 2 in http://www.ann-geophys.net/28/927/2010/ angeo-28-927-2010-supplement.zip) clearly indicate that horizontal winds control the movements of cloud systems as well as of low $T_{100}$ systems. Since the areas of both cloud and low $T_{100}$ systems are mainly confined to $10-20^{\circ} \mathrm{N}$ and $75-120^{\circ} \mathrm{E}$, these features closely resemble the tropical easterly jet (TEJ), indicating that cloud and low $T_{100}$ systems are closely linked to TEJ.

\subsubsection{Role of convection generated gravity waves}

The role of convection-generated gravity waves (GW) in cooling the temperature in tropopause region is examined by critically analyzing the temperature profiles obtained from GPS-sondes launched from ORV Sagar Kanya. Wave structure is observed to modulate the vertical temperature profile. Figure 9 shows a typical example, where temperature profile, perturbations from mean and the spectrum of temperature perturbations are shown for 24 August 1999, 00:00 GMT. The wave amplitude is $\sim 1-4 \mathrm{~K}$ with a mean value of $2.2 \mathrm{~K}$ and the vertical wavelength is in the range of $1.2-9.6 \mathrm{~km}$ with a mean value of $3.0 \pm 2.6 \mathrm{~km}$ (Table 3 ). The convectiongenerated GW with a dominant period of $23-49 \mathrm{~min}$ is reported by Kumar (2006) from the observations made by using Indian MST Radar at Gadanki $\left(13.5^{\circ} \mathrm{N}, 79.2^{\circ} \mathrm{E}\right)$.

The present observations indicate modulation of temperature in upper tropospheric and lower stratospheric region by convection-generated GW. These waves may also spread 
the cooling eastward (i.e. upwind) through formation of ice clouds (Potter and Holton, 1995). However, in the present study, GW effects in spreading the areas of cooling could not be separated out from the wind effects.

\section{Summary}

The objective of the present study was to understand the association between the convection activity and occurrence of extremely low temperatures in tropopause region using the observations from multiple platforms. The observations are summarized as follows:

1. The seasonal movement of the ITCZ is evident. In northern summer monsoon season, intense convection activity with CTT of $\sim 173-193 \mathrm{~K}$ is observed. These CTT,s are noted to be cooler than the expected ambient temperature. It is also noted that clouds with lower CTT lie within the area of low OLR, indicating that these are convective clouds, though presence of cirrus clouds along with convective clouds cannot be completely ruled out.

2. Low temperature in tropopause region and intense convection activity (i.e. low OLR) occur in the same broad area. Areas of LTT and of low OLR do not always overlap. In cases where area of low $T_{100} / T_{\mathrm{CPT}}$ does not overlap the low OLR area, the value of OLR at such locations is greater than $160 \mathrm{~W} \mathrm{~m}^{-2}$. Multiple centers of enhanced convection (low OLR) are observed on number of days and areas of low $T_{100} / T_{\mathrm{CPT}}$ appear in between such low OLR areas. These observations point out that the mechanisms, one suggested by Danielsen (1982) and the other one suggested by Sherwood (2000), have a role in the troposphere-to-stratosphere transport of air. On the days when both the mechanisms are operating, geographical areas where the two mechanisms are operating would naturally be separated.

3. Westward propagating Rossby waves of the period of $\sim 15$ days are observed to modulate both OLR and $T_{100}$ over the Indian land mass (ILM) region. This again indicates a close association between the two phenomena. A cross-correlation analysis between OLR and $T_{100}$ time series shows that OLR leads in phase by $\sim 5$ days.

4. An examination of series of high resolution cloud imageries show that cloud systems as well as the areas of occurrence of low $T_{100}$ both move under the influence of horizontal winds. It is also noted that movement of the cloud systems and that of areas of low $T_{100}$ is closely linked with TEJ winds which appear over this region during Asian summer monsoon.
Acknowledgements. The authors thank India Meteorological Department (IMD) for making available the radiosonde and satellite data. They are thankful to William B. Rossow for making available ISCCP-DX data. The ECMWF ERA-40 data used in this study have been provided by ECMWF. Observations under BOBMEX campaign were funded by the Department of Science and Technology (DST), Government of India. The authors had much useful discussions with G. S. Bhat of IISc Bangalore and S. K. Subramanian of IMD. One of the authors (VP) is grateful to CSIR, India for the award of Senior Research Fellowship. Present work is supported by ISRO/DOS, Government of India, through a research project under CAWSES- India Program. The authors are also thankful to the Director, National Physical Laboratory, New Delhi and HOD, Radio and Atmospheric Sciences Division for supporting the present research work.

Topical Editor P. Drobinski thanks M. Pope for his help in evaluating this paper.

\section{References}

Bhat, G. S., Gadgil, S., Hareesh Kumar, P. V., Kalsi, S. R., Madhusoodanan, Muthy, V. S. N., Prasada Rao, C. V. K., Ramesh Babu, V., Rao, L. V. G., Rao, R. R., Ravichandran, M., Reddy, K. G., Sanjeeva Rao, P., Sengupta, D., Sikka, D. R., Swain, J., and Vinayachandran, P. N.: BOBMEX: The Bay-of-Bengal Monsoon Experiments, B. Am. Meteorol. Soc., 82, 2217-2243, 2001.

Bhat, G. S., Chakarbarty, A., Nanjundiah, R. S., and Srinivasan J.: Vertical structure of the atmosphere during active and weak phases of convection over the north Bay of Bengal: Observation and model Results, Current Sci., India, 83(3), 296-302, 2002.

Bhat, G. S.: Some salient features of the atmosphere observed over the north Bay-of-Bengal during BOBMEX, Proc. Indian Acad. Sci., 112, 131-146, 2003.

Blackman, R. E. and Tukey, J. W.: The measurement of Power Spectra from the point of view of communication engineers, Dover Publications, Inc., Newyork, pp. 14-15, 1959.

Brewer, A. W.: Evidence for a world circulation provided by the measurement of helium and water vapor distribution in the stratosphere, Q. J. Roy. Meteorol. Soc., 75, 351-363, 1949.

Cornford, S. G. and Spavins, C. S.: Some measurements of cumulonimbus tops in the pre-monsoon season in north-east India, Meteorl. Mag., 102, 314-332, 1973.

Danielsen, E. F.: A dehydration mechanism for the stratosphere, Geophys. Res. Lett., 9, 605-608, 1982.

Dhaka, S. K., Yamamoto, M. K., Shibagaki, Y., Hashiguchi, H., Fukao, S., and Chun, H.-Y.: Equatorial Atmosphere Radar observations of short vertical wavelength gravity waves in the upper troposphere and lower stratosphere region induced by localized convection, Geophys. Res. Lett., 33, L19805, doi:10.1029/2006GL027026, 2006.

Gettelman, A., Salby, M. L., Randel, W. J., and Sassi, F.: Convection in the tropical tropopause region and stratospheretroposphere exchange, SPARC Newsl., 17, 22-25, 2001.

Gettelman, A., Salby, M. L., and Sassi, F.: Distribution and influence of convection in the tropical Tropopause region, J. Geophys. Res., 107(D10), 4080, doi:10.1029/2001JD001048, 2002.

Holton, J. R. and, Gettelman, A.: Horizontal transport and dehydration in the stratosphere, Geophys. Res. Lett., 28, 2799-2802, 2001. 
Holton, J. R., Curry, J. H., and Payle, J. A.: Inter Tropical Convergence Zone in Encyclopedia of Atmospheric Science, 6, 23252334, 2003.

Jain, A. R., Das, S. S., Mandal, T. K., and Mitra, A. P.: Observation of extremely low tropopause temperature over the Indian tropical region during monsoon and post monsoon months: Possible implications, J. Geophys. Res., 111, D07106, doi:10.1029/2005JD005850, 2006

Jain, A. R., Johny, C. J., Panwar, V., Mandal, T. K., Rao, V. R., Gautam, R., and Dhaka, S. K.: Occurrence of extremely low cold point temperature during Summer monsoon: ARMEX campaign and CHAMP/COSMIC satellite observations, J. Geophys. Res., in review, 2010.

Jiang, J. H., Wang, B., Goya, K., Hocke, K., Eckermann, S. D., Ma, J., Wu, D. L., and Read, W. G.: Geographical distribution and interseasonal variability of tropical deep convection: UARS MLS observations and analyses, J. Geophys. Res., 39, D03111, doi:10.1029/2003JD003756, 2004.

Kalnay, E., Kanamitsu, M., Kistler, R., Collins, W., Deaven, D., Gandin, L., Irendall, M., Saha, S., White, G., Woolen, J., Zhu, Y., Chelliah, M., Ebisuzaki, W., Higgins, W., Janowiak, J., Mo, K. C., Ropelewski, C., Wang, J., Leetma, A., Reynolds, R., Jenne, R., and Joseph, D.: The NCEP /NCAR 40-year reanalysis project., B. Am. Meteorol. Soc., 77, 437-470, 1996.

Kim, H. and Dessler, A. E.: Observations of convective cooling in the tropical tropopause layer in AIRS data, Atmos. Chem. Phys. Discuss., 4, 7615-7629, 2004, http://www.atmos-chem-phys-discuss.net/4/7615/2004/.

Kumar, K. K.: VHF radar observations of convectively generated gravity waves: Some new insights. Geophys. Res. Lett., 33, L01815, doi:10.1029/2005GL024109, 2006.

Kuang, Z. and Bretherton, C. S.: Convective influence of the heat balance of the Tropical Tropopause layer: A cloud resolving model study, J. Atmos. Sci., 61, 2919-2927, 2004.

Lyons, S. W.: Origins of convective variability over equatorial southern Africa during Austral Summer, J. Climate, 4, 23-39, 1991.

Morwal, S. B. and Kumar, R. V.: Indian climate Research Programme, The Bay of Bengal monsoon experiment (BOBMEX). A comprehensive report on CD (CD-Rom), Indian Institute of Tropical Meteorology, Pune, India, 2002.
Okoola, R. E.: Spatial evolutions of the active monsoon pattern across the equatorial eastern Africa during northern hemisphere spring season using outgoing long wave radiation, Meteorol. Atmos. Sci., 66, 51-63, doi:10.1007/BF0103448, 1998.

Newell, R. E. and Stewart, G.: A stratospheric fountain?, J. Atmos. Sci., 38, 2789-2796, 1981.

Pommereau, J.-P. and Held, G.: Is there a stratospheric fountain?, Atmos. Chem. Phys. Discuss., 7, 8933-8950, 2007, http://www.atmos-chem-phys-discuss.net/7/8933/2007/.

Potter, B. E. and Holton, J. R.: The role of monsoon convection in dehydrating of the lower tropical stratosphere, J. Atmos. Sci., 52, 1034-1050, 1995

Rao, P. B., Jain, A. R., Kishore, P., Balamuralidhar, P., Damle, S. H., and Viswanathan, G.: Indian MST Radar 1. System description and sample vector wind measurement in ST mode, Radio Sci., 30(4), 1125-1138, 1995.

Rossow, W. B. and Schiffer, R. A.: Advances in understanding clouds from ISCCP, B. Am. Meteorl. Soc., 80, 2261-2288, 1999.

Rossow, W. B. and Pearl, C.: 22-year survey of tropical convection penetrating into the lower stratosphere, Geophys. Res. Lett., 34, 4, doi:10.1029/2006GL028635, 2007.

Sherwood, S. C.: A Stratosperic 'Drain' over the maritime continent, Geophys. Res. Lett., 27, 677-680, 2000.

Sherwood, S. C. and Dessler, A. E.: A model for transport across the tropical tropopause, J. Atmos. Sci., 58, 765-779, 2001.

Sherwood, S. C. and Dessler, A. E.: Convective mixing near the tropical tropopause: Insight from seasonal variations, J. Atmos. Sci., 60, 2674-2685, 2003.

Sherwood, S. C., Horinouchi, T., and Zeleznik, H. A.: Convective impact on temperatures near the tropical tropopause, J. Atmos. Sci., 60, 1847-1856, 2003.

Titelbaum, M., Moustaoui, M., Basdevant, C., and Holton, J. R.: An alternative mechanism explaining hygropause formation in the tropical region, Geophys. Res. Lett., 27, 221-224, 2000.

Tsuda, T., Murayama, Y., Wiryosumarto, H., Harijono, S. W. B., and Kato, S.: Radiosonde observations of the equatorial atmosphere dynamics over Indonesia, J. Geophys. Res., 99, 1050710516, 1994.

Vomel, H., Oltmans, S. J., Kley, D., and Crutzen, P. J.: New evidence for the stratospheric dehydration mechanism in the equatorial Pacific, Geophys. Res. Lett., 22, 3235-3238, 1995. 